\title{
Endo- $\beta$-mannanase enzyme activity in the structures of Coffea arabica L. seeds under different types of processing and drying
}

\author{
Valquíria Fátima Ferreira ${ }^{1}\left(\right.$ Marcela Andreotti Ricaldoni $^{1}(\%)$ \\ Sttela Dellyzete Veiga Franco da Rosa $^{2^{*}} \cdot$ Madeleine Alves de Figueiredo $^{1}$ \\ Stefânia Vilas Boas Coelho ${ }^{1}$ ) Tatiana Botelho Fantazzini $^{1}$ ( )
}

${ }^{1}$ Departamento de Agricultura, Universidade Federal de Lavras (UFLA), Campus da UFLA, Lavras, MG, Brasil.

${ }^{2}$ Empresa Brasileira de Pesquisa Agropecuária, Embrapa Café, Parque Estação Biológica (PqEB), 70770-901, Brasília, DF, Brasil. E-mail: sttela.rosa@embrapa.br. "Corresponding author.

ABSTRACT: Enzymes play a fundamental role in degradation of molecules during seed germination, development, and deterioration. Endo$\beta$-mannanase is one of the main enzymes responsible for hydrolysis of mannans in the endosperm during germination of coffee seeds through its action in hydrolytic degradation of cell walls and in weakening the structures of the endosperm that surround the embryo, allowing radicle emergence. The aim of this study was to determine the activity of the endo- $\beta$-mannanase enzyme in the structures of coffee seeds for the purpose of assessing the relationship between this activity and the physiological quality of the seeds under different processing and drying methods. Coffea arabica L. fruit in the cherry maturity stage was subjected to three different types of processing: natural (seeds maintained in the fruit itself), fully washed (fruit pulped mechanically and the seeds demucilaged by fermentation in water), and semi-washed or demucilaged (both fruit pulp and mucilage removed mechanically); and two methods of drying: slow drying (suspended screen) in the shade, and rapid drying in mechanical dryer at $35^{\circ} \mathrm{C}$ to a moisture content of $11 \pm 1 \%$. After processing and drying, the physiological quality of the seeds was evaluated through the germination test, and endo- $\beta$-mannanase enzyme activity was quantified. Coffee seeds submitted to natural processing have lower physiological performance, as well as greater deterioration and greater activity of the endo- $\beta$-mannanase enzyme. Removal of mucilage during fully washed and semi-washed processing of coffee seeds reduces the activity of the endo- $\beta$-mannanase enzyme and lowers deterioration, especially after faster drying. The enzyme endo-ß-mannanase is efficient in studying of the effects of processing and drying on coffee seeds, and can be evaluated in whole seeds, endosperms or embryos.

Key words: metabolic reactions, hydrolysis of mannans, Coffea arabica $L$.

Atividade da enzima endo-ß-mananase nas estruturas de sementes de Coffea arabica $\mathbf{L}$. submetidas a diferentes tipos de processamentos e secagem

RESUMO: As enzimas têm papel fundamental na degradação de moléculas durante a germinação, desenvolvimento e deterioração das sementes. A endo-ß-mananase é uma das principais responsáveis pela hidrólise das mananas no endosperma durante a germinação das sementes de café, atuando na degradação das paredes celulares e enfraquecimento do endosperma que circunda o embrião, permitindo a protrusão da radícula. Objetivou-se nesta pesquisa determinar a atividade da endo-beta-mananase nas estruturas das sementes de café, para avaliar a relação entre esta atividade e a qualidade de sementes submetidas a diferentes processamentos e métodos de secagem. Frutos de Coffea arabica L. no estádio de maturação cereja foram submetidos a três tipos de processamento: natural (sementes mantidas nos próprios frutos), despolpado (frutos descascados mecanicamente e sementes desmuciladas por fermentação em água) e desmucilado (frutos descascados e a mucilagem removida, ambos mecanicamente), como também a dois métodos de secagem: lenta à sombra (telado suspenso) e secagem rápida em secador mecânico a $35^{\circ} \mathrm{C}$, até umidade de $11 \pm 1 \%$. Após o processamento e secagem avaliou-se a qualidade fisiológica das sementes pelo teste de germinação e quantificou-se a atividade da enzima endo-ß-mananase. Sementes de café submetidas ao processamento natural tem menor desempenho fisiológico, assim como maior deterioração e maior atividade da enzima endo-ß-mananase, principalmente após secagem mais rápida. A remoção da mucilagem durante o processamento despolpado e desmucilado de sementes de café reduz a atividade da enzima endo- $\beta$-mananase e também a deterioração. A secagem rápida em secador afeta negativamente a qualidade das sementes. A enzima endo- $\beta$-mananase é eficiente no estudo dos efeitos do processamento e secagem em sementes de café, podendo ser avaliada em sementes inteiras, endospermas ou embriões.

Palavras-chave: reações metabólicas, hidrólise das mananas, Coffea arabica L.

\section{INTRODUCTION}

Enzymes play a fundamental role in various metabolic reactions, both in synthesis and in degradation of molecules during seed germination, development, and deterioration. Thus, they can be used as markers of these processes.

Various factors can affect seed germination. Endosperm is one of the structures that surround the embryo, and it can retard or prevent 
seed germination, acting as a physical barrier to radicle emergence (SILVA et al., 2005; BISOGNIN et al., 2008; REGO et al., 2011). For the germination process to occur, some enzymes act to degrade the endosperm, increasing the speed and the percentage of seed germination, thus facilitating radicle growth and emergence (NASCIMENTO et al., 2002).

Coffee seeds have a resistant layer, the endosperm, that surrounds the embryo and that can contribute to delay germination. This endosperm must be ruptured because it constitutes a barrier, imposed by the tissues of the endosperm surrounding the embryo (FREITAS et al., 2017). The region where the radicle emerges, called endosperm cap, is composed of high cellulose and hemicellulose polysaccharide content, which confers resistance and protection to the embryo (SILVA et al., 2005; EIRA et al., 2006).

Some authors have affirmed that for seed germination to occur, the endosperm cap must be weakened through the activity of the endo- $\beta$-mannanase enzyme, as occurs in seeds of several species, such as Datura ferox (ARANA et al., 2006), peppers (Capsicum spp.) (CAIXETA et al., 2014), coffee (Coffea arabica L.) (SILVA et al., 2004), and lettuce (Lactuca sativa) (ALBUQUERQUE et al., 2010).

Endo- $\beta$-mannanase is considered one of the main enzymes responsible for hydrolysis of the mannans present in the endosperm cap during coffee seed germination, acting in hydrolytic degradation of the cell walls and in the process of weakening the structures of the endosperm that surround the embryo, thus allowing primary root emergence (SILVA et al., 2004; SCHRÖDER et al., 2009).

Loss in quality of coffee seeds is related to the post-harvest treatments of processing and drying. Dry processing consists of drying the whole fruit, i.e., with exocarp (hull), mesocarp (pulp and mucilage), and endocarp (parchment), giving rise to what is known as dry cherry coffee or natural coffee (BORÉM, 2008). Furthermore, according to the author, wet processing, which gives rise to parchment coffees, can be carried out in different manners: mechanical removal of the hull or pulp and part of the mucilage gives rise to pulped coffee; mechanical removal of the hull or pulp and removal of the mucilage by biological fermentation gives rise to fully-washed coffee; and mechanical removal of the hull or pulp and of the mucilage gives rise to semiwashed coffee.

Currently, high temperatures are often applied for faster drying of natural coffees, and lower temperatures for fully-washed coffees. This procedure is adopted through the belief that since the natural coffee beans/seeds are still in the fruit, they are more resistant to drying and less exposed to damage than the fully-washed coffee beans/seeds. However, results obtained from some authors confirmed that wet processed (fully-washed) coffees are more tolerant to drying than dry processed (natural) coffees (TAVEIRA et al., 2015).

Nevertheless, these post-harvest treatments affect endo- $\beta$-mannanase enzyme activity and the chemical constitution and integrity of the enzyme systems, affecting physiological quality of coffee seeds (SAATH et al., 2014; TAVEIRA et al., 2015).

The aim of this study was to determine endo- $\beta$-mannanase enzyme activity in the structures of soaked coffee seeds for the purpose of evaluating the relationship between this activity and the effects of different processes and drying methods of coffee fruit on the physiological quality of coffee seeds.

\section{MATERIALS AND METHODS}

The study was conducted in the Central Seed Laboratory of the Agriculture Department of the Universidade Federal de Lavras, Lavras, MG, Brazil. Coffea arabica L. fruits were collected in the cherry maturity stage and subjected to three different types of processing: natural (seeds maintained in the fruit itself), fully washed (mechanically pulped fruit and mucilage removed from the seeds through fermentation in water for 24 hours at $25^{\circ} \mathrm{C}$ ), and semi washed (fruit pulped and mucilage removed both mechanically). Two drying methods were used: one slower drying method in the shade on a suspended screen, and another more rapid drying method in a mechanical dryer at a temperature of $35^{\circ} \mathrm{C}$ until the seeds reached moisture content of $11 \pm 1 \%$. Natural coffees were dried in the fruit itself, and the fullywashed and semi-washed coffees were dried in their parchment. After processing and drying, the seeds were evaluated for their physiological quality by the germination test, in which the percentage of normal seedlings was determined, according to the guidelines of the Rules for Seed Analysis (BRASIL, 2009), with germination papers moistened in distilled water, at a $30^{\circ} \mathrm{C}$ for 30 days. The percentage of strong normal seedlings was also evaluated (considered as those with a hypocotyl length greater than or equal to $2 \mathrm{~cm}$ ), as well as the percentage of seedlings with expanded cotyledonary leaves at 45 days after sowing.

Evaluation of endo- $\beta$-mannanase enzyme activity was determined in whole coffee seeds and in embryos and endosperms separated from the seeds after soaking in distilled water for 10 days 
under a constant temperature of $30^{\circ} \mathrm{C}$. Whole seeds, embryos, and endosperms were ground up in a mill cooled to $4^{\circ} \mathrm{C}$ in the presence of antioxidant polyvinylpyrrolidone (PVP).

In microtubes containing $200 \mathrm{mg}$ of ground seeds, $600 \mu \mathrm{L}$ of extraction buffer was added containing $0.1 \mathrm{M}$ Hepes and $0.5 \mathrm{M} \mathrm{NaCl}(\mathrm{pH} 8.0)$ plus ascorbic acid at the rate of $5 \mathrm{mg}$ of acid for each $\mathrm{ml}$ of buffer. After that, the microtubes were vortexed for 1 minute and centrifuged at $10,000 \mathrm{~g}$ for 30 minutes at $4{ }^{\circ} \mathrm{C}$. The supernatant was applied to gel prepared with $6 \mathrm{~mL}$ of LBG (Locust Bean Gum-Sigma), 0.24g of agarose (Qbiogene), and $24 \mathrm{~mL}$ of buffer, $\mathrm{pH} 5.0$. Gel casters were covered with Gel Bond ${ }^{\circledR}$ Film and gel was applied to them, and after solidification, the gel was stored in a refrigerator for 24 hours and was then pierced with a $2 \mathrm{~mm}$ diameter punch. The quantity of $2 \mu \mathrm{L}$ of enzyme extract were applied to each hole, with 3 replications of each sample. For the enzyme present in the extract to act, the gel was kept in a germinator at a $25^{\circ} \mathrm{C}$ for 21 hours in the dark in a moist chamber (plastic trays lined with two sheets of paper towel moistened in distilled water and sealed with plastic wrap).

For reading, the gel was first washed in distilled water, then washed in buffer solution (gel buffer) for 30 minutes, and once more washed in distilled water. The gel was covered with $0.5 \%$ Congo red dye for 30 minutes and placed in ethanol for 10 minutes to remove the dye. After removing the ethanol with distilled water, a $1 \mathrm{M} \mathrm{NaCl}$ solution was added until visual observation of white halo formation in the holes containing the samples. At that time, the diameter of the samples was measured with a caliper rule. A standard curve generated by the commercial endo- $\beta$-mannanase of Aspergillus niger (Megazyme) was used to calculate endo- $\beta$ mannanase enzyme activity, in accordance with DOWNIE et al. (1994).
Results of physiological evaluation were analyzed in a completely randomized design in a $3 \times 2$ factorial arrangement, consisting of three methods of processing the fruit (natural, fully-washed, semiwashed) and two methods of drying (slow drying, and rapid drying in a dryer), with four replications. Results of endo- $\beta$-mannanase enzyme activity were analyzed in a completely randomized design in a $3 \times 3 \times 2$ factorial arrangement, composed of three methods of processing the fruit (natural, fullywashed, semi-washed), three different structures of seeds (whole seed, embryo, and endosperm) and two methods of drying (drying in the shade and in a dryer), with three replications. Data were subjected to analysis of variance and mean values were compared by the Scott-Knott test $(\mathrm{p}>0.05)$ through the statistical program SISVAR (FERREIRA, 2011).

\section{RESULTS AND DISCUSSION}

According to the results of analysis of variance, in physiological evaluation of Coffea arabica L seeds, a significant effect of interaction was reported on the processing and drying factors on the results of normal seedlings as evaluated in the germination test 30 days after sowing. There was a significant effect of the processing and drying factors separately for strong normal seedlings and expanded cotyledonary leaves.

The physiological performance of naturally processed coffee seeds was lower compared to that of fully-washed and semi-washed seeds, considering the percentage of strong normal seedlings and of seedlings with expanded cotyledonary leaves (Table 1).

In the coffee seeds originating from fullywashed and semi-washed fruit, there was an increase in physiological quality, and this may be related to the effect of these manners of processing on the chemical and enzymatic composition of the seeds (FREITAS et

Table 1 - Percentage of strong normal seedlings and seedlings with expanded cotyledonary leaves originating from coffee seeds under different manners of processing.

\begin{tabular}{lcc}
\hline Processing & Strong normal seedlings & Seedlings with expanded cotyledonary leaves \\
\hline Fully washed & $71 \mathrm{a}$ & $30 \mathrm{a}$ \\
Semi washed & $70 \mathrm{a}$ & $38 \mathrm{a}$ \\
Natural & $25 \mathrm{~b}$ & $16 \mathrm{~b}$ \\
CV $(\%)$ & 20.31 & 41.02 \\
\hline
\end{tabular}

${ }^{*}$ Mean values followed by the same letter in the column do not differ from each other by the Scott-Knott test at $5 \%$ probability.

Ciência Rural, v.48, n.12, 2018. 
al., 2017). Some authors affirmed that fully-washed coffees have superior beverage characteristics compared to natural coffees (SELMAR et al., 2006; BYTOF et al., 2007). This difference should not be attributed only to the form of processing, but also to the occurrence of undesirable fermentations that are often associated with dry processing, as well as lack of care at the time of harvest and drying of natural coffee (BORÉM, 2008). Damage to coffee seeds during the processing and drying steps has been indicated as one of the main causes of loss of physiological quality (ZONTA, 2008).

In this study, the drying method also affected the physiological quality of coffee seeds since there was a significant decline in quality in seeds subjected to rapid drying in a mechanical dryer, as can be observed by the higher percentages of strong normal seedlings and seedlings with expanded cotyledonary leaves after slow drying, compared to rapid drying (Table 2). These results corroborate the results of VIEIRA et al. (2007), who reported that rapid drying decreases the vigor and viability of coffee seeds.

Studies performed on coffee have shown the effect of processing and drying methods on the physiological quality of seeds, as well as physical and biochemical changes that may affect aroma and flavor (BYTOF et al., 2007; BORÉM, 2008). During the drying process, seeds undergo physical changes, brought about by temperature and moisture gradations that lead to reduction in the percentage and speed of germination, and also increase the percentage of abnormal seedlings (ZONTA, 2008).

At 30 days after sowing, coffee seeds that underwent slow drying, regardless of the form of processing, had better physiological performance than the seeds that underwent rapid drying and were under the natural and semi-washed processes; the other treatments were not different from each other (Table 3). Coffee seeds under natural processing and rapid drying had lower physiological quality than the other treatments, which were not different from each other in regard to the drying used.

Reduction in the physiological quality of coffee seeds when they are dried within the fruit itself (natural coffee), compared to parchment coffees (fully-washed coffee), has been attributed to undesirable fermentations that may occur during drying (SAATH et al., 2014; TAVEIRA et al., 2015). In addition to undesirable fermentations, natural processing may cause biochemical and physiological changes that hurt the physiological performance of coffee seeds. From these results, it can be inferred that natural coffees are more sensitive to stresses than parchment coffees. A possible explanation for this is the fact that dry processed (natural) coffees are exposed to drying air for longer periods, exposing the endosperm and the embryo to more severe thermal damage and contributing to greater loss of cell membrane activity (SAATH et al., 2014; TAVEIRA et al., 2015).

Regarding the results of endo- $\beta$ mannanase enzyme activity, in coffee seeds soaked for 10 days, there was significant triple interaction of the processing $\times$ drying $\times$ seed structure factors. When seeds were subjected to slow drying, greater endo$\beta$-mannanase enzyme activity was reported in the embryo of the naturally processed seeds (Table 4).

In coffee seeds under rapid drying, greater expression of endo- $\beta$-mannanase was observed in the endosperm of seeds that passed through natural processing. In this same manner of processing, lower expression of the enzyme was observed in whole seeds when under rapid drying. In fully-washed and semi-washed seeds, there were no significant differences in the different structures analyzed in regard to rapid or slow drying.

When whole seeds were used for determination of endo- $\beta$-mannanase activity there were no significant differences, regardless of the type

Table 2 - Percentage of strong normal seedlings and seedlings with expanded cotyledonary leaves originating from coffee seeds under different drying methods.

\begin{tabular}{lcc}
\hline Drying method & Strong normal seedlings & Seedlings with expanded cotyledonary leaves \\
Rapid & $41 \mathrm{~b}$ & $17 \mathrm{~b}$ \\
Slow & $64 \mathrm{a}$ & $36 \mathrm{a}$ \\
CV $(\%)$ & 20.31 & 41.02 \\
\hline
\end{tabular}

*Mean values followed by the same letter in the column do not differ from each other by the Scott-Knott test at 5\% probability.

Ciência Rural, v.48, n.12, 2018. 
Table 3 - Normal seedlings at 30 days originated from coffee seeds under different types of processing and drying methods.

\begin{tabular}{|c|c|c|}
\hline \multirow[t]{2}{*}{ Processing } & -------- & ----- \\
\hline & Slow & Rapid \\
\hline Fully washed & 88Aa & $82 \mathrm{Aa}$ \\
\hline Semi-washed & $93 \mathrm{Aa}$ & $83 \mathrm{Ab}$ \\
\hline Natural & $85 \mathrm{Aa}$ & $27 \mathrm{Bb}$ \\
\hline CV (\%) & -------. & -------- \\
\hline
\end{tabular}

* Mean values followed by the same lowercase letter in the line and uppercase letter in the column do not differ from each other by the Scott-Knott test at $5 \%$ probability.

of processing and the drying method. The enzyme activity determined in the endosperms of seeds under slow drying also did not differ in regard to the manners of processing used. However, greater activity of the endo- $\beta$-mannanase enzyme was reported in seeds under natural processing, in the endosperm and in the embryo of seeds under rapid drying, and in the embryos of seeds that were under slow drying (Table 4).

This result may be related to greater loss of quality in seeds kept in the fruit (natural processing) during drying, which was also observed in other studies. These seeds remain in the fruit for a longer time during drying, accelerating the deterioration process and thus increasing the activity of the enzyme that is directly linked with deterioration, or, otherwise, the longer drying time of seeds under natural processing may lead to denaturation of some enzymes (SAATH et al., 2014). The activity of the endo-ß-mannanase enzyme also occurs in coffee seeds during storage, showing evidence of its relationship to an advancing deterioration process (VEIGA et al., 2007).

In contrast, different results have been observed, in which there was reduction in endo- $\beta$ - mannanase enzyme activity during the storage of lettuce seeds; i.e., the greater the deterioration, the lower the activity of this enzyme (PIMENTEL et al., 2012).

Although, significant differences were not reported, a tendency of reduction in endo- $\beta$ mannanase enzyme activity is observed in seeds that passed through the mucilage removal process, in all the seed structures (Table 4).

According to table 5, rapid drying led to reduction in endo- $\beta$-mannanase activity in whole seeds and in the embryos of coffee seeds under natural processing; however, lower enzyme activity was reported in endosperms when slow drying and natural processing were used. The other treatments did not differ from each other, regardless of the drying, processing, or structure used.

These results corroborate those reported by DUSSERT et al. (2006), who affirmed that during processing and drying of seeds and grains, changes may occur in the relative composition of phospholipids of membranes in the synthesis of heat resistant proteins and in the ability of seeds to prevent, tolerate, or repair damage from free radicals.

Table 4 - Endo- $\beta$-mannanase enzyme activity in whole seeds and in different structures of coffee seeds under different types of processing and drying methods.

\begin{tabular}{|c|c|c|c|c|c|c|}
\hline \multirow[t]{2}{*}{ Processing } & \multicolumn{3}{|c|}{ 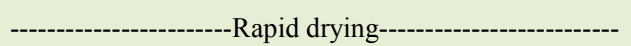 } & \multicolumn{3}{|c|}{ 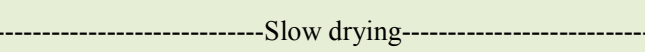 } \\
\hline & Whole seeds & Endosperms & Embryos & Whole seeds & Endosperms & Embryos \\
\hline Natural & $2.01 \mathrm{Ac}$ & $11.29 \mathrm{Aa}$ & $6.27 \mathrm{Ab}$ & $6.13 \mathrm{Ab}$ & $6.12 \mathrm{Ab}$ & $32.72 \mathrm{Aa}$ \\
\hline Fully washed & 3.07Aa & $3.68 \mathrm{Ba}$ & 2.49Ba & $4.75 \mathrm{Aa}$ & $4.73 \mathrm{Aa}$ & $3.27 \mathrm{Ba}$ \\
\hline Semi-washed & $2.06 \mathrm{Aa}$ & $1.82 \mathrm{Ba}$ & $2.27 \mathrm{Ba}$ & $2.15 \mathrm{Aa}$ & $3.48 \mathrm{Aa}$ & $3.27 \mathrm{Ba}$ \\
\hline
\end{tabular}

"Mean values followed by the same lowercase letter in the line and uppercase letter in the column do not differ from each other by the Scott-Knott test at $5 \%$ probability. 
Table 5 - Endo- $\beta$-mannanase enzyme activity in whole seeds and in different structures of coffee seeds under different types of processing and drying methods.

\begin{tabular}{|c|c|c|c|c|c|c|}
\hline \multirow[t]{3}{*}{ Processing } & \multicolumn{2}{|c|}{ - } & \multicolumn{2}{|c|}{--------Endosperms---------- } & \multicolumn{2}{|c|}{ 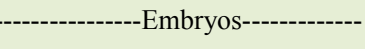 } \\
\hline & \multicolumn{6}{|c|}{------------------------------------------------------------Drying methods-------------------------------------------------------- } \\
\hline & Rapid & Slow & Rapid & Slow & Rapid & Slow \\
\hline Natural & 2.01B & $6.13 \mathrm{~A}$ & $11.29 \mathrm{~A}$ & $6.12 \mathrm{~B}$ & $6.27 \mathrm{~B}$ & $32.72 \mathrm{~A}$ \\
\hline Fully washed & 3.07A & $4.75 \mathrm{~A}$ & $3.68 \mathrm{~A}$ & $4.73 \mathrm{~A}$ & $2.49 \mathrm{~A}$ & $3.27 \mathrm{~A}$ \\
\hline Semi-washed & $2.06 \mathrm{~A}$ & $2.15 \mathrm{~A}$ & $1.82 \mathrm{~A}$ & $3.48 \mathrm{~A}$ & $2.27 \mathrm{~A}$ & $3.27 \mathrm{~A}$ \\
\hline
\end{tabular}

${ }^{*}$ Mean values followed by the same uppercase letter in the line do not differ from each other by the Scott-Knott test at $5 \%$ probability.

Seeds under natural processing remain within the fruit, under the action of compounds present in the exocarp, in the mesocarp, and in the endocarp, favoring the oxidation process, leading to deterioration of coffee seeds. These structures make for greater moisture transfer to the seeds within them, which may favor the beginning of the process of weakening the structures of the endosperm that surround the embryo. This promotes an increase in activity of the cellulase enzyme, followed by an increase in endo- $\beta$-mannanase activity (SCHRÖDER et al., 2009).

Furthermore, the pericarp imposes a certain restriction on gas exchanges, increasing seed respiration and, consequently, deterioration, increasing the activity of enzymes directly connected with deterioration, as is the case of endo- $\beta$-mannanase, as reported in this study.

\section{CONCLUSION}

Coffee seeds submitted to natural processing have lower physiological performance, as well as greater deterioration and greater activity of the endo- $\beta$-mannanase enzyme. Removal of mucilage during fully washed and semi-washed processing of coffee seeds reduces the activity of the endo-ß-mannanase enzyme and lowers deterioration, especially after faster drying. The enzyme endo- $\beta$ mannanase is efficient in studying of the effects of processing and drying on coffee seeds, and can be evaluated in whole seeds, endosperms or embryos.

\section{ACKNOWLEDGMENTS}

Our thanks to the Empresa Brasileira de Pesquisa Agropecuária (EMBRAPA), to the Fundação de Amparo à Pesquisa do Estado de Minas Gerais (FAPEMIG), and to the
Instituto Nacional de Ciência e Tecnologia do Café (INCT Café) for the resources and scholarships provided.

\section{DECLARATION OF CONFLICTING INTERESTS}

The authors declare no conflict of interest. The founding sponsors had no role in the design of the study; in the collection, analyses, or interpretation of data; in the writing of the manuscript, and in the decision to publish the results.

\section{AUTHORS' CONTRIBUTIONS}

All authors contributed equally for the conception and writing of the manuscript. All authors critically revised the manuscript and approved of the final version.

\section{REFERENCES}

ALBUQUERQUE, K.A.D. et al. Physiological and biochemical quality of lettuce seeds coated with micronutrients, amino acids and growth regulators. Bioscience Journal, v.26, n.6, p.843-848, 2010. Available from: $<$ http://www.seer.ufu.br/index.php/biosciencejournal/ article/viewFile/7216/6603>. Accessed: Jan. 17, 2018.

ARANA, M.V. et al. A phytochrome-dependent embryonic factor modulates gibberellin responses in the embryo and micropylar endosperm of Datura ferox seeds. Planta, v.223, n.4, p.847-857, 2006. Available from: $<$ https://www.bing.com/search?q=A+phy tochromedependent + embryonic + factor + modulates + gibberellin + responses + in + the + embryo + and + micropylar + endosperm + of $+D$ aturaferox + seeds \& form $=$ IE9TR $\& s r c=I E 9 T R \& p c=$ MDDRJS $>$. Accessed: Feb. 22, 2018. doi: 10.1007/s00425-005-0134-7.

BORÉM, F.M. et al. Secagem do café. In: BORÉM, F.M. Póscolheita do café. Lavras: Editora UFLA, 2008. Cap.7, p.127-58.

BRASIL. Ministério da Agricultura, Pecuária e Abastecimento. Regras para análise de sementes. Secretaria Nacional de Defesa Agropecuária. Brasília: MAPA/ACS, p.395, 2009.

BYTOF, G. et al. Transient occurrence of seed germination processes during coffee post-harvest treatment. Annals of Botany, v.100, n.1, p.61-66, 2007. Available from: $<$ https://www. researchgate.net/publication/6350862_Transient_Occurrence_ 
of_Seed_Germination_Processes_during_Coffee_Post_Harvest_ Treatment>. Accessed: Feb. 22, 2018. doi: $10.1093 / \mathrm{aob} / \mathrm{mcm} 068$.

CAIXETA, F. et al. Physiological and biochemical alterations during germination and storage of habanero pepper seeds. African Journal of Agricultural Research, v.9, n.6, p.627635, 2014. Available from: <https://www.researchgate.net/ publication/287343196_Physiological_and_biochemical_ alterations_during_germination_and_storage_of_habanero pepper_seeds>. Accessed: Feb. 22, 2018. doi: 10.5897/ AJAR2013.7133.

DOWNIE, B. et al. A new assay for quantifying endo- $\beta$-mannanase activity using Congo Reddye. Phytochemistry, v.36, n.4, p.829835, 1994. Available from: <https://www.sciencedirect.com/ science/article/abs/pii/S0031942200904461>. Accessed: Mar. 11, 2018. doi: 10.1016/S0031-9422(00)90446-1.

DUSSERT, S. et al. Oxidative stress, phospholipid loss and lipid hydrolysis during drying and storage of intermediate seeds. Physiologia Plantarum, v.127, n.2, p.192-204, 2006. Available from: <http:// onlinelibrary.wiley.com/doi/10.1111/j.1399-3054.2006.00666.x/full>. Accessed: Jan. 17, 2018. doi: 10.1111/j.1399-3054.2006.00666.x.

EIRA, M.T.S. et al. Coffee seed physiology. Brazilian Journal of Plant Physiology, v.18, n.1, p.149-163, 2006. Available from: $\quad<\mathrm{http}$ ://www.scielo.br/scielo.php?script=sci_arttext\&pid $=$ S1677-04202006000100011 $>$. Accessed: Feb. 22, 2018. doi: $10.1590 /$ S1677-04202006000100011.

FERREIRA, D.F. SISVAR: A computer statistical analysis system. Ciência e Agrotecnologia, v.35, n.6, p.1039-1042, 2011. Available from: <http://www.scielo.br/scielo.php?script=sci ar ttext\&pid $=$ S1413-70542011000600001>. Accessed: Feb. 22 , 2018. doi: 10.1590/S1413-70542011000600001.

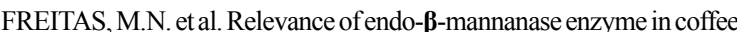
seed deterioration process. African Journal of Agricultural Research, v.12,n.15,p.1253-1258, 2017. Available from: $<$ http://academicjournals. org/journal/AJAR/article-abstract/B1C8BFD63666>. Accessed: Mar. 11, 2018. doi: 10.5897/AJAR2016.10949.

NASCIMENTO, W.M.; CANTLIFFE, D.J. Germinação de sementes de alface sob altas temperaturas. Horticultura Brasileira v.20, n.1, p.103-106, 2002. Available from: $<$ http://www.scielo.br/ scielo.php?script $=$ sci arttext $\&$ pid $=\mathrm{S} 0102-05362002000100020>$. Accessed: Jan. 17, 2018. doi: 10.1590/S0102-05362002000100020.

PIMENTEL, M.A. et al. Ação de diferentes enzimas na germinação de sementes de alface (Lactuca sativa L.) - Asteraceae. Journal of Biotechnology Biodiversity, v.3, n.3, p.1-4, 2012. Available from: $<$ https://sistemas.uft.edu.br/periodicos/index.php/JBB/article/ view/288/201>. Accessed: Jan. 17, 2018.

REGO, S.S. et al. Estresse Hídrico e Salino na Germinação de Sementes de Anadenanthera colubrina (Veloso) Brenan. Journal of Biotechnology and Biodiversity, v.2, n.4, p.3742, 2011. Available from: <https://www.researchgate.net/ publication/260290132 Estresse Hidrico e Salino na Germinacao_de_Sementes_de_Anadenanthera_colubrina_ Veloso_Brenan>. Accessed: Feb. 22, 2018.
SAATH, R. et al. Activity of some isoenzymatic systems in stored coffee grains. Ciência e Agrotecnologia, v.38, n.1, p.15-24, 2014. Available from: <http://www.scielo.br/scielo.php?script=sci arttext\&pid $=$ S1413-70542014000100002 $>$. Accessed: Feb. 22 , 2018. doi: 10.1590/S1413-70542014000100002.

SCHRÖDER, R. et al. Re-interpreting the role of endo- $\beta$ mannanases as mannan endotransglycosylase/hydrolases in the plant cell wall. Annals of Botany, v.104, n.2, p.197-204, 2009. Available from: <https://www.ncbi.nlm.nih.gov/pmc/articles/ PMC2710900/>. Accessed: Mar. 11, 2018. doi: 10.1093/aob/ mcp 120 .

SELMAR, D. et al. Germination of coffee seeds and its significance for coffee quality. Plant Biology, v.8, n.2, p.260264, 2006. Available from: <https://www.ncbi.nlm.nih.gov/ pubmed/16547871>. Accessed: Mar. 11, 2018. doi: 10.1055/s2006-923845.

SILVA, E.A. et al. Abscisic acid controls embryo growth potential and endosperm cap weakening during coffee (Coffee arabica L., cv. Rubi) seed germination. Planta, v.220, n.2, p.251-261, 2004. Available from: <https://www.ncbi.nlm.nih. gov/pubmed/15309536>. Accessed: Jan. 17, 2018. doi: 10.1007/ s00425-004-1344-0.

SILVA, E.A. et al. Exogenous gibberellins inhibit coffee (Coffea arabica cv. Rubi) seed germination and cause cell death in the embryo. Journal of Experimental Botany, v.56, n.413, p.1029-1038, 2005. Available from: <https://www.ncbi. nlm.nih.gov/pubmed/15723829>. Accessed: Mar. 11, 2018. doi: 10.1093/jxb/eri096.

TAVEIRA, H.S.J. et al. Post-harvest effects on beverage quality and physiological performance of coffee beans. African Journal of Agricultural Research, v.10, n.12, p.1457-1466, 2015. Available from: <http://academicjournals.org/journal/AJAR/ article-abstract/2E6001E51866>. Accessed: Mar. 11, 2018. doi: 10.5897/AJAR2014.9263.

VIEIRA, A.R. et al. Armazenamento de sementes de cafeeiro: ambientes e métodos de secagem. Revista Brasileira de Sementes, v.29, n.1, p.76-82, 2007. Available from: <http://www.scielo. br/scielo.php?pid=S0101-31222007000100011\&script $=$ sci abstract\&tlng=pt $>$. Accessed: Feb. 22, 2018. doi: 10.1590/S010131222007000100011

VEIGA, A.D. et al. Armazenabilidade de sementes de cafeeiro em diferentes estádios de maturação e submetidas a diferentes métodos de secagem. Revista Brasileira de Sementes, v.29, n.1, p.83-91, 2007. Available from: <http://www.scielo.br/ scielo.php? pid $=$ S0101-31222007000100012\&script $=$ sci abstract\&tlng $=p t>$. Accessed: Jan. 17, 2018. doi: 10.1590/S010131222007000100012

ZONTA, J.B. et al. Uso do teste Lercafé para a caracterização de danos em sementes de cafeeiro. Pesquisa Agropecuária Brasileira, v.43, n.11, p.1601-1607, 2008. Available from: $<$ http:// www.scielo.br/scielo.php?script $=$ sci abstract\&pid $=$ S0100-204X2 008001100020\&lng=pt\&nrm=i>. Accessed: Mar. 11, 2018. doi: 10.1590/S0100-204X2008001100020. 